\title{
AN EXAMINATION OF THE CSÍKSOMLYÓ SHRINE BASED ON THE TOURIST LIFE CYCLE CURVE
}

\author{
Anett TOZSER \\ Research Institute for National Strategy, Directorate for Research, \\ Strategy and Coordination, 8, Nagysándor József street, Budapest, 1054, Hungary, e-mail: anett.tozser@nski.gov.hu
}

\begin{abstract}
Citation: Tozser, A. (2020). AN EXAMINATION OF THE CSÍKSOMLYÓ SHRINE BASED ON THE TOURIST LIFE CYCLE CURVE. GeoJournal of Tourism and Geosites, 32(4), 1304-1309. https://doi.org/10.30892/gtg.32417-573
\end{abstract}

\begin{abstract}
The Csíksomlyó Pilgrimage is a tradition that also has a history hundreds of years long, and one of the examples stressing the importance of religious tourism known by many even today. The goal of this study is to research the story, touristic importance and everchanging role of the Csíksomlyó Pilgrimage, mainly from the perspective of the Csíksomlyó Pilgrimage being a touristic product, what phase of its life cycle it is currently, what way it's developing right now, and what future it's heading towards. According to the examination on the tourist life cycle curve, the farewell to Csíksomlyó is currently in the phase of development and consolidation. All stakeholders agree that it is necessary to develop the tourism infrastructure for renewal.
\end{abstract}

Key words: religious tourism, pilgrimage, pilgrim, shrine, Csíksomlyó, Csíksomlyó Shrine

$* * * * *$

\section{INTRODUCTION}

Csíksomlyó, as a fundamental place for Szeklerland's sacred practice has a history of hundreds of years, and also became one of the most important shrine area for the Hungarian nation. The Csíksomlyó Pilgrimage is a tradition that also has a history hundreds of years long, and one of the examples stressing the importance of religious tourism known by many even today. On a regional scale, the shrine of Csíksomlyó also became one of the most well-known brand, which offers its services - beyond spiritual pleasures - to approximately 250.000 visitors each year. Csíksomlyó is the largest pilgrimage site of the Hungarian people, and became a positive example of religious tourism for everyone in the last 30 years. This year it was included in the collection of Hungaricums. The Csíksomlyó pilgrimage has a significant role in strengthening beliefs and the national self-awareness, furthermore, it has a major effect on Transylvania's and Hungary's touristic development, since it generates a huge customer traffic, and consuming. Given that, according to expert estimates, up to $60 \%$ of the 1.2 million tourists who travel to Transylvania each year may be Hungarian (Nagy, 2013), an important objective is to evaluate the impact of the event, which has great significance for the attractive tourism of Csíksomlyó and Csíkszereda.

The Csíksomlyó pilgrimage has a significant role in strengthening beliefs and the national self-awareness, furthermore, it has a major effect on Transylvania's and Hungary's touristic development, since it generates a huge customer traffic, and consuming. Given that, according to expert estimates, up to $60 \%$ of the 1.2 million tourists who travel to Transylvania each year may be Hungarian (Nagy, 2013), an important objective is to evaluate the impact of the event, which has great significance for the attractive tourism of Csíksomlyó and Csíkszereda.

The goal of the research is to examine what value the Csíksomlyó Pilgrimage has as a touristic product, what effect it has on the tourism of the region, and what are its economic effects in Transylvania. This required us to use the method of data evaluation to examine the volume of the pilgrimage's traffic, use the life cycle phase curve to measure the scale and orientation of current development, and to conduct interview with the Franciscan provincial chief of Transylvania. During the research, we made the following hypothesis: the Csíksomlyó Pilgrimage is still mainly considered an important asset for experiencing religious beliefs by the church, but its function as strengthening the self-awareness of Hungarians, and experiencing their unity also became a strong motivational factor.

\section{MATERIAL AND METHODS}

During our research, we used both primary and secondary methods.We processed literary sources of this topic: that shed light on the connections between religious and cultural tourism (Bona et al., 2020; Bond et al., 2015; Mintel, 1992; Santos, 2003; Smith, 1992; Stausberg, 2011; Suntikul and Dorji, 2016; Vukonic, 2002; Irimiás and Michalkó, 2013; Mester, 2006; Raffay et al., 2014; Varga, 2011; Fábián, 2010), the Csíksomlyó Pilgrimage, and the spiritual and national charm (Harangozó, 2003; Harkányi et al., 2011; Mohay, 2006; Mohay, 2009; Tőzsér and Bánhidai, 2016; Vörös, 2005).

Using the methodology of document analysis, we evaluated the prior research that exists for the topic: sociological context of the pilgrimage's ever-changing role, statistical research on the number of participants, and the research papers looking at the product palette of the pilgrimage as a tourist destination, and its development state. We examined the Csíksomlyó farewell according to the tourist life cycle curve. An interview was conducted with Erik Urbán, the provincial leader of the Transylvanian Franciscans and the church director of the Franciscan monastery of Csíksomlyó in order to integrate the opinions and experiences of the expert of the topic into the results of the research on the changing role and economic significance of the Csíksomlyó farewell.

\section{RESULTS AND DISCUSSION}

\section{Interpretation and importance of religious tourism}

Religious tourism is a form of touristic product continuously in development within the tourism sector. This is mainly due to how the most influential beliefs in the world are on the rise currently, and secondly due to how many tourists include spiritual loca tions in their touristic goals when they travel (Mintel, 2012). The growth of religious tourism also brought the expansion of visitor numbers with it. Mintel (2012) estimates that in 2015, 46 million religious tourists began their pilgrimage to sacred sites. The amount religi ous tourists spend on average is estimated to be around $1.000 \$$, which can be tens of billions of dollars for the entire business. Therefore, religious

\footnotetext{
${ }^{*}$ Corresponding author
} 
tourism is a significant product within the tourism sector, which uses its attractiveness to make specific and exemplary tourism attractions a target for research, like the Csíksomlyó Pilgrimage. Religious tourism doesn't have a unified definition. Experts determine the phenomenon with significant differences, but multiple unified and constant connections can also be found.

The most important general perspective of interpreting religious tourism is that most authors' consensus suggests that religious tourism itself must have some sort of spiritual, cultural interest and respect of varying intensity to the religious tourist (pilgrim), which they put into action by visiting a spiritually important destination (architectural heritage or natural treasure site).

UNWTO (2011) describes religious tourism as any kind of travel to destinations outside of our milieu which is taken due to be liefs or spiritual initiative. Domestic literature suggests the first examined definition may also be the one that's the easiest to interpret. It goes as follows: religious tourism is when people visit a place, building, or shrine, because they consider it to be sacred (Mester, 2006). The author categorised religious tourism into three groups based on the definition:

- Pilgrimage;

- taking part in a spiritual event;

- cultural religious tourism (visiting a temple or a shrine, not due to reasons of beliefs, but because of its cultural, historical and architectural importance).

In this definition, we can consider how the author differentiates between tourists visiting the sacred place based on their motivational reasons to be one of the cornerstones. The basis of interpreting religious tourism is the motivation of travellers visiting the shrine (which may be either spiritual or cultural). Furthermore, the author differentiates between travellers with spiritual motivation as well, and breaks them down into further groups (those attending a spiritual event, and those taking part in a pilgrimage).

Mintel's definition (2012) also shows the many facets of religious tourism, which states religious tourism is the occasion when someone visits buildings, locations or shrines considered to be holy. This activity was categorised into the following groups:

- pilgrimages;

- visiting spiritual areas due to them being considered sacred;

- travelling to spiritual events;

- "temple treks" (visiting a temple's shrine due to the cultural, historical and architectural importance, instead of reasons related to beliefs).

Based on the opinion of authors who wrote another report dealing with religious tourism (Raffay et al., 2014), religious tourism basically consists of services and touristic products reserved for visitors with a spiritual and cultural motivation, that are based on spiritual values.

Varga (2011) considers the definition of religious tourism an attribute structure, where the word refers to tourism and the message is of spirituality and beliefs. The author expands on the explanation's duality when making the definition itself, because the religious nature carries an implicit sacred meaning on the one hand, and since it means a profit-oriented activity due to the nature of tourism on the other hand. She smoothly calls this duality the question of "business or content".

We can see general connections when defining religious tourism which are present in all definitions. These are mainly apparent when describing the interests of the religious (or cultural) tourist: a common basis for different definitions is that there is the presence of belief, but on varying levels. And the main difference between definitions interpreting religious tourism should be searched for in the subjective factors impossible to measure, and common to tourism, since these are the source of differences. This difference appears in the different natures, levels, and the actual motivations of travellers, of the interest we talked about before. Different authors categorise tourists into different groups based on their motivations and preferences. And this means the spiritual or cultural pilgrimage to sacred sites due to respect or interest, as we're talking about religious tourist (Mester, 2006; Mintel, 2012; Raffay et al., 2014; Santos, 2003; Smith, 1992; Stausberg, 2011).

This is exactly why determining the goals of visitors, which can't be objectively measured, questions the problems of making a definition apparent. Different studies handle people taking part in religious tourism in different ways. The stricter perspective says that only events where memorials or buildings of the Church are visited by people with strong beliefs, due to religious faith-related reasons can be considered religious touristic events (Mester, 2006; Mintel, 2012), while the more lax approach believes that either travellers with or without strong beliefs visiting well-known spiritual sites counts as religious tourism (Raffay et al., 2014; Vukonic, 2002).

As for the Csíksomlyó Pilgrimage, we had to focus on the fact that though Whitsun as a Christian holiday bases on Christian values, and the pilgrimage offers this holiday worthy exposure, during the definition's wording, we found that choosing the more lax approach is beneficial due to the different motivations of visitors, in case visiting the pilgrimage and sacred locations is considered religious tourism, regardless of the existence or intensity of beliefs.

Researching the Whitsun Pilgrimage is a special question due to how the holiday persists for four days, and this fact significantly changes the results of the research, in light of who we consider to be a member of the pilgrimage. The height of the pilgrimage is considered to be the mass on Saturday, and the so-called cross tread route going under banners and settlement name signs. As the interview conducted in the Grey friar monastery of Csíksomlyó also suggested, the number of members partaking in the pilgrimage can't be generalised from the Church's perspective either, as the Church considers pilgrimage to be the result of a religious process, which includes the spiritual placation, repentance, and forgiveness. In most cases, this means that most of the pilgrims only spend a single day on Whitsun in Csíksomlyó.

\section{Connections between religious and cultural heritage tourism}

Prior decades brought a change in the nature of religious tourism based on the changing needs of travellers, due to the technological development and social changes. Religious- and cultural tourism's borderlines are introduced in Figure 1, which was modelled by Smith (1992) during his research into religious tourism.

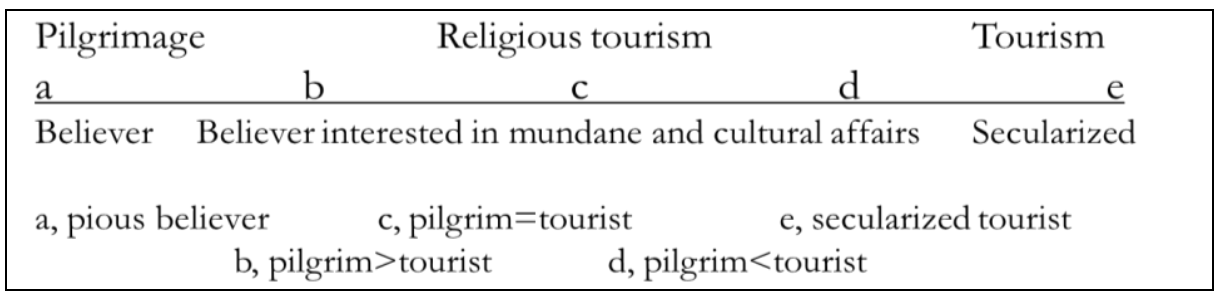

Figure 1. Connections and differences between religious and cultural heritage tourism (Source: author, based on Smith, 1992) 
As the illustration also suggests, pilgrimage, religious tourism and cultural tourism don't differ significantly from each other. While the traveller interested in cultural treasures can be called more of a tourist, the traveller in search of God, fuelled by their faith is more of a pilgrim. This transience is what significantly raises the hurdle for researching the topic, and objectively evaluating the precise measurement of results, as faith and spiritual interests due to beliefs are impossible to study from the perspective of total visitor count.

Bona et al. (2020) also found that as secularization has accelerated, a growing number of anthropological studies have illuminated the sacred-secular bipolarity between pilgrimage and tourism and between pilgrims and tourists. The topic of the spectrum from sacred to secular and from pilgrims to tourist remains arguably the foremost issue in research on religious tourism.

Some of the authors also state during their definition that religious tourism is mainly a part of cultural tourism, as those interested in religious tourism are interested in visiting mainly culture historical, art historical, or etymological treasures. These visitors can be categorised into two different groups: either the experience of beliefs and spiritual memories, or the experience of seeing culture historical, art historical, or etymological treasures compel them to visit the given tourist destination (Bona et al., 2020; B ond et al., 2015; Suntikul and Dorji, 2016; Irimiás and Michalkó, 2013; Varga, 2011). Religious tourism in case of the Csíksomlyó Pilgrimage is also considered to be a part of the cultural tourism (Tőzsér and Bánhidai, 2016), as those taking part also have the motivation of experiencing the Hungarian cultural background in a belief-related and national context, apart from their relation to faith.

\section{The Csíksomlyó pilgrimage - spiritual and/or national destination?}

In Csíksomlyó's case, the problem of designating the boundaries of religious tourism also comes up, since the Csíksomlyó Pilgrimage isn't a spiritual experience from the perspective of faith exclusively, but also an important location of experiencing the Hungarian identity in the context of the Church.

The Csíksomlyó Pilgrimage retained its reliance on faith purely for hundreds of years, as a holiday of the Church. Based on sources from said Church, Csíksomlyó has been a location for religious pilgrimages since 1444. This was declared by Pope Eugene IV. in one of his concordats that exists even today. Since 1567, the pilgrimage is a sacramental pilgrimage, which is the point where we can trace the Csíksomlyó Whitsun Pilgrimage back to. The oldest sources place the construction of the Csíksomlyó Shrine to the $15^{\text {th }}$ century. The temple survived the Turkish Occupation, which beliefs and national traditions consider to be the results of the Virgin Mary statue bringing forth miracles, kept in the temple (Vörös, 2005).

Due to the spiritual-physiological healing that often happened in Csíksomlyó, Ignác Batthyány, the bishop of Transylvania declared the Virgin Mary statue a miracle in 1789. The Virgin Mary reverence is further elevated by the Regnum Marianum circle, which stated that King Saint István offered his nation and country to the Virgin Mary in the form of the crown representing it. In light of this, the settlers crowding into the country, and the local Hungarian people found their common Virgin Mary reverence as a point to connect, and the Catholic Hungarian nation was united via this reverence irrelevant to ethnic groups. This is how the statue, and Csíksomlyó became the cultural centre and the symbol of keeping faith for Szeklerland, and later, Transylvania through the years. The century-old tradition of pious Virgin Mary reverence during the Whitsun Holiday was significantly cracked by the political and social changes of the $20^{\text {th }}$ century. In 1949 , the reigning Romanian regime prohibited the pilgrimage. Though this prohibition was in effect until 1990, the local settlements kept sending pilgrims in the decades it persisted to Csíksomlyó (Mohay, 2006; Mohay, 2009; Vörös, 2005).

Multiple studies deal with the different motivations for visiting the pilgrimage (Mohay, 2006; Mohay, 2009; Vörös, 2005; Harangozó, 2003; Harkányi et al., 2011). Taking part in the Csíksomlyó Pilgrimage changed from its initial form of being an event dedicated to Catholic faith into a modern and popular belief tourism destination, due to the historical changes the $20^{\text {th }}$ century brought about. The Catholic faith still holds a significant role in their motivation, and the pious visits they do to the other Christian believers on the grounds of being ecumenical, but nowadays, visitors with basically no pious belief, but persisting Christian roots have at least this much significance as well, whose main motivation is to experience national self-representation with the Hungarians coming from the Carpathian Basin and other areas of the World. In the following part, we'll summarise perspectives and opinions.

Earlier research suggest that the touristic interest for the event was first caused in the 1970's-1980's, when young intellectuals from Budapest flocked to the Somlyó Pilgrimage because they could meet Csango people there (Mohay, 2006).

In the later 1990's, the fact that people going to the pilgrimage were not fundamentally from a regional, Szeklerlandian region, but from a broader distance, became a more significant fact. Ever since the 1990's, people from the entire area of Transylvania and Hungary have been coming to the pilgrimage, and even other places inhabited by Hungarians, and countries beyond the sea represent themselves (Mohay, 2006).

The international popularity of the pilgrimage, which rose quickly, was partly due to the reporting of mass communication tools, like newspapers reporting from the pilgrimage, and radio- and television programmes. This process brought forth the changes in the Church's holiday. This is how the self-representation in national categories became the main reason for those participating, taking over motivation resulting from faith (Vörös, 2005).

Based on the results of prior research also featured in this study, we can say that the Whitsun Pilgrimage in Csíksomlyó is also communicated as a national holiday by politics and the media, even though it's basically a holiday of the Church, which is how they advance the visitation of Hungarians en masse. Despite this, the emotional relation of the masses visiting the holiday to the message of the holiday isn't only due to this, as it's more of a collective national community experience of the mass of people present. The national symbols, like the signs and flags held up by people during the march are a significant means to this (Vörös, 2005).

Therefore, we can state that the Csíksomlyó Pilgrimage went through various changes in meaning since the time of 1990, which made it differ from its spiritual meaning, and these changes represent national elements in the design of the holiday. However, this shouldn't solely be searched for in the changes the holiday's meaning went through. Beliefs play a significant role (both catholic and protestant beliefs) in keeping the Hungarian identity in Transylvania, mostly due to historical reasons, which is why it's hard to differentiate between motivations fuelled by faith and national aspect when comparing people visiting the pilgrimage. Based on the experience of the interview, we can say that experiencing faith is significant in the motivation to visit the pilgrimage, which lets us believe that the opportunity of experiencing their faith in a region housing a strong Hungarian community 500 kilometres from the border is what attracts the mass of visitors (Mohay, 2006; Mohay, 2009; Vörös, 2005; Tőzsér and Bánhidai, 2016).

\section{Analysing the Csíksomlyó pilgrimage destination using the lifecycle curve}

Tourism destinations have differing attributes, which is why the nature of tourism and the changes caused are very different for each one, but similar processes can be seen for all tourism destinations. This process is what the destination lifecycle model wants to represent on a theoretical level, which starts from the fact that the demand for the local tourism destination is in relation with the attitude locals have towards tourism, and the current development state of the tourism sector (Butler, 2011; Palancsa, 2007). 
The most well-known tourism lifecycle curve is Butler's model (1980). Butler believes the tourism lifecycle curve consists of six consecutive phases. The various phases bring different amounts (each more or less than others) and types of visitors, and have different development levels and tourism-brought effects (Butler, 2011; Palancsa, 2007) (Figure 2).

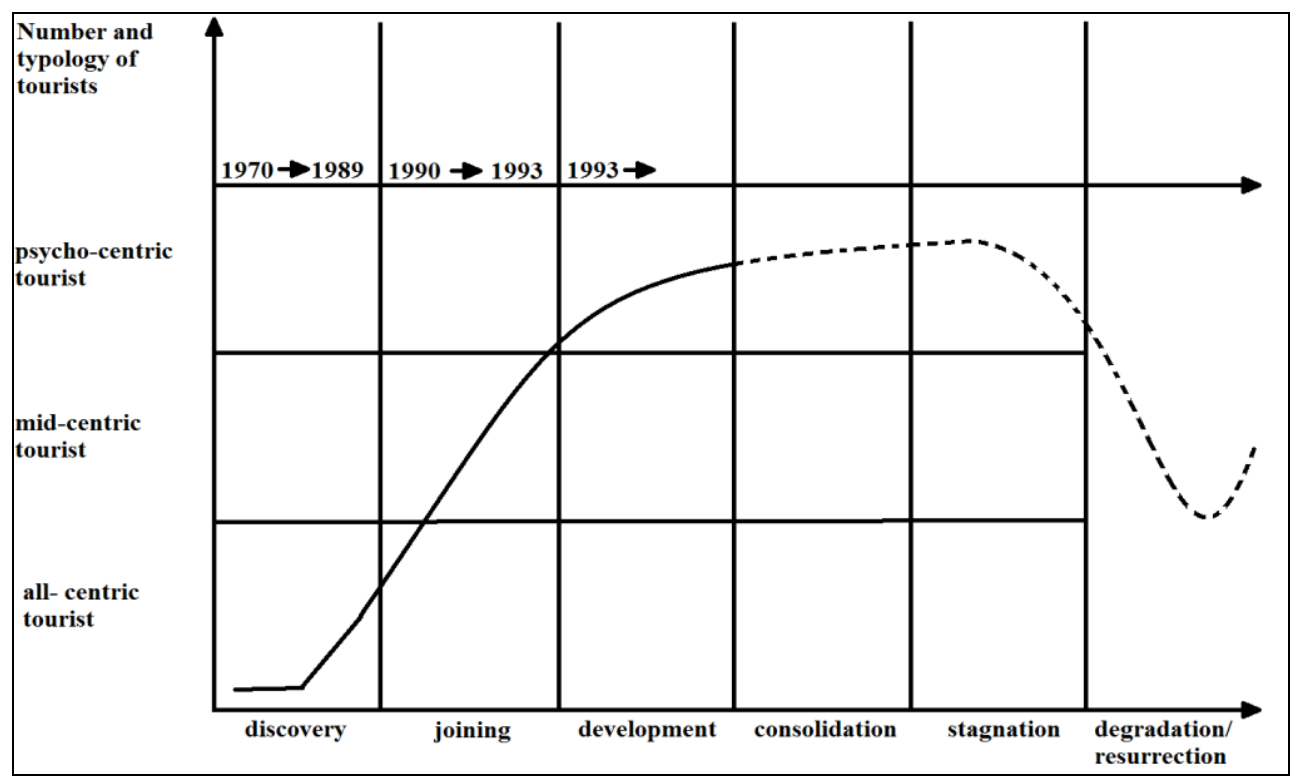

Figure 2. Tourism destination lifecycle curve model (Source: author, based on Palancsa, 2007)

The theory of the lifecycle curve has multiple weaknesses. One of these is that the exact number of visitors is unknown, or that there is no data for the structure of visitors, which makes precise illustration impossible.

To familiarise ourselves with the lifecycles of the Csíksomlyó Pilgrimage, we have to briefly introduce the tourist types in the model using Plog's tourism research perspective (Plog, 2001).

Plog's analysis can be considered ground-breaking with its starting point, as it researched tourists as it would a population. The fundamental questions of the analysis are openness, acceptance, interest in new and unusual experiences, and how much tourists are attracted to known, familiar experiences. Based on these points, Plog differentiated between three types of tourists (Plog, 2001).

1. Allo-centric type: those wishing for entirely new experiences, and visiting completely unknown destinations, tourists representing one end of the spectrum. They are a risk-taking type, searching for areas, people and situations which differ from their usual lifestyle.

2. Psycho-centric type: the other end of the spectrum. Tourists searching for the absolutely known, the feeling of "just like home".

3. Mid-centric type: the tourist type placed between the two ends of the spectrum, which represents the most generic traveller's perspective. Looks for new experiences, but in home-like environments if possible.

As all models, the Plog-type tourist-types also have problems: the interpretation and experiencing of "new experiences" and "home-like environments" can be different for people with differing cultural and social backgrounds. However, since the actual topic of our research is the Csíksomlyó Pilgrimage and its visitors, we can generally say that there are no significant differences thanks to the identical or similar pious and cultural background. Szeklers and Hungarians taking part in the pilgrimage have similar preferences, and their motivation is basically to experience their national identity in a religious context.

Today, the Csíksomlyó Pilgrimage is one of the most well-known element of Transylvania's tourism offers, and hundreds of thousands of visitors arrive here annually. The seasonal tourism influenced by the pilgrimage as well also has an economic effect in the region: Harghita County accepts the highest number of tourists in the main season of summer.

The tourism lifecycle curve suggests the Csíksomlyó Pilgrimage is currently on the border of the development and consolidation phases. The research conducted on-site also supported that the number of visitors coming to the pilgrimage can only be estimated, and this number is on the rise, becoming higher each year. The basis of using the tourism destination / product model for the analysis is that the theoretic starting points of the model are cross-referenced with data at hand.

According to the theoretical model, the first phase is the timeframe of discovery in a destination's (currently, a tourism product's) life.

This timeframe, based on the Butler thesis (Butler, 2011) means that a small number of generally all-centric tourists visit. These tourists are here in the name of exploration, and are interested in novelties. As the tourism destination doesn't have a tourism infrastructure, tourism itself has no significant economic, social or cultural effects. The area is hard to approach, and the interest is generated basically by natural treasures.

In the case of the Csíksomlyó Pilgrimage, the phase of discovery was the timeframe between 1970 and 1989 . In the phase of discovery, theory and practice were almost perfectly aligned. Interest in the pilgrimage became more apparent from the 1970's, when intellectuals from Budapest with a wanderlust were the main visitors, coming to meet Csangos (Mohay, 2006).

The next phase of the model is the phase of joining. Based on the theory's description, developing the tourism infrastructure begins in this phase, mostly for lodging and guest services. The first investors appear, and the tourist season, which means the highest visitor count is also determined. Tourists come into direct contact with locals.

The timeframe of joining happened between 1990 and 1993 for the Csíksomlyó Pilgrimage. After the year of the political change, the amount of visitors that come to take part in the pilgrimage was on the rise. From the few university students visiting the event until 1989 , a huge crowd grew that became interested in it, and it was so numerous that the shrine wasn't able to welcome visitors anymore. After the Romanian Communist Regime fell, most of the people appearing at the first pilgrimage were from Transylvania. The mass and the pilgrimage were first held on the square before the shrine where the visitors were, and were later re-directed to the valley of Mt. Somlyó, where the open-area shrine's construction begun. "The mass of people was so huge that the entire area was crippled. The mass was on the square before the temple at that time, and there were too many people that we had to take it out to the valley" (Erik Urbán's interview). 
The phase of joining is followed by the phase of development, which is in the process of happening, and started in 1993, based on currently available data. Based on the theoretic description of the model, this timeframe is basically when the mass of visitors grow: the number of people visiting increases beyond the number of locals. At the same time, the number of local entrepreneurships also increases, and the intensity of marketing-communications is also on the rise. Attractions made by man exchange the primary function of natural and cultural interests.

During the development phase of the Csíksomlyó Pilgrimage, pilgrims from the entirety of Hungary and Transylvania arrive, while the Carpathian Basin's Hungarians and other countries from beyond the sea also represent themselves. As the interview conducted in the Grey friar monastery of Csíksomlyó also suggested, the development of touristic products can also be dated here. By relocating the pilgrimage from the shrine to the valley of Mt. Somlyó, the Church made the conditions applicable to accepting hundreds of thousands of visitors, but the open-area shrine planned by architect Imre Makovecz was also constructed to this end in 1996. Based on the opinions of expert asked during the interview, we can say that the capacity of hotels, hostels and private housing was also made during these years, which is expanding even today, and is capable of serving the hundreds of thousands of people arriving for the pilgrimage.

The phase of consolidation is described by a decelerating growth, and the search for new markets. To keep visitor number high, an intense marketing-communication activity is happening. Psycho-centric tourists appear between the visitors, and investors from abroad also start appearing in the economic life of the destination. The life quality of locals deteriorates, and resentment towards tourists also appears.

Today's Csíksomlyó Pilgrimage can be described with the developing tourism infrastructure, the continuing construction of the Virgin Mary Road, the partaking in the Recultivatur international religious tourism project, and the expansion of the Church's programs. According to the interview, making Csíksomlyó an attractive place even outside of the pilgrimage became the focus. Accepting visi tors, and offering them programs, spiritual placation and practices not only at the Whitsun holiday, but during the entirety of the year also became important. This process is evident, thanks to the online communication (blogs of grey friars, websites of Hungarian travel agencies), and the programs of the Virgin Mary Road Community.

The next phase of Butler's thesis is the stagnation. This is where the number of visitors reaches the limit of the area's capacity. The most notable effects are from insufficient exploitation and strong seasonality. The appearance of mass tourists signifies that the destination became an outdated fad. The dependence on returning tourists becomes strong, and entrepreneurships often change leaders.

Based on the interviewee's experience, the increase in numbers visiting the Csíksomlyó Pilgrimage is still happening, but a kind of deceleration can be felt. The increase in marketing intensity can be felt in print and online media, lodgings that are open are reserved for the pilgrimage months before the event itself happens. The popularity of the destination persists. We can feel a strong seasonality, and pilgrim programs aren't significant yet.

The last phase of our analysed model is degradation. In this phase, mass tourists choose not to visit, entrepreneurships cease to function, and the touristic infrastructure deteriorates. Seasonality becomes relevant for the entire year, while tourists search for new destinations.

Degradation isn't in effect for the Csíksomlyó Pilgrimage, as a touristic product currently, but for this to persist, the ren ewal of the event is necessary, which came into the planning phase last year.

Based on the analysis, the Csíksomlyó Pilgrimage shows both the attributes of the development and those of the consolidation phases of the lifecycle curve analysis at the same time. The increase in visitor count is still significant, but shows a decelerating tendency. The number of visitors is many times over that of locals, tourism sprouts more and more entrepreneurships, but many opportunities are still buried within the destination's attributes, to which the region seems to react, in the form of development plans for the time being.

The product palette of the pilgrimage is constant, its contents stagnate, but all persons of interests agree on how the touristic infrastructure has to be developed for the renewal process, which mainly consists of summarising capacities at hand, and collecting the local stakeholders of tourism.

\section{CONCLUSIONS}

The goal of this research is basically to evaluate the changing form, and the national and touristic importance of the Csíksomlyó Whitsun Pilgrimage. Summarising the research, we can say that the 30 years that went by since 1990, the year that brought popularity to the pilgrimage organised for the $453^{\text {rd }}$ time in 2020 , can be considered insignificant compared to the historical frame of the shrine's existence. However, 30 years is more than enough to prove that the holiday attracting hundreds of thousands for four days is on the rise, and its popularity is ever-increasing, even today. This process is long-term, and worth investing in.

The data collected during the analysis, and the tourist destination lifecycle curve model employed for using said data both suggest that the increase in interest is continuous, even if it's following a slightly decelerating tempo. This practically means that since 1990, people visiting the event are more numerous every year, but we can't talk about an exponentially increasing mass of visitors anymore.

During the on-site research, once again, we were able to prove that though the Grey friars deal with organising the pilgrimage alone, the huge volume of the event doesn't make it unsuccessful, both from a sacrilegious perspective (as pious believers have four days to experience spiritual practices), and from a touristic perspective (as both guests and locals accept the mass coming to the pilgrimage with persistent hospitality each year). The pilgrimage is also successful from an economic perspective, so to say: though we don't have precise data on this, during the interviews, the focus turned to how SMEs can also profit from the visitors that come during Whitsun; supported by both the leaders of the mundane and the religious worlds during their respective interviews.

As for environmental effects, we didn't find any negative impact either. The nature of the event guarantees that visitors behave themselves appropriately, and this also develops in the proper way.

During the on-site research, our hypothesis which suggests that the pilgrimage re-orientated to a mundane, national event didn't hold true. Based on the experiences, the original nature and goals of the pilgrimage were kept intact, moreover, the Church's primary goal experiencing faith - is still the most notable factor. Due to the occupation of the Church, this event isn't handled as a touristic product, which is why touristic validation isn't a primary condition.

The Csíksomlyó Pilgrimage, as a touristic research topic doesn't have a long history. In recent years, multiple media products and organisations tried to measure the number of people visiting the pilgrimage using some sort of method. The research planned to continue from the current point requires that a methodology for measuring the visitor count is made, and used to conduct measurements.

Based on the experiences from Transylvania, local demands prioritise a well-thought out touristic infrastructural development. The shrine and its direct constructed environment are under national heritage protection, meaning implementing construction projects on a large scale is practically impossible. As for developments, the main demand is to renovate Church-owned buildings, and the construction of a Grey friar museum, which could introduce the 500-year history of the Grey friars to visitors, and their amassed spiritual and physical treasures. 
All significant actors (friars, civilians, municipality) consider awakening the interest incoming tourists have in Csíksomlyó the most important task, not only during the pilgrimage, but beyond that as well, and to keep people who visit the area in place for as long as possible. In order to realise this, they try to increase the interest in religious tourism using events of the Church, and organising spiritual practices, and via different projects and the initiatives of civilian organizations.

Csíksomlyó, as a touristic destination depends significantly on the Whitsun Pilgrimage for its development. In order to avoid falling into the trap of seasonality, and to make the area a religious goal of tourists during the entire year, a more intentional, professional and thoughtout marketing practice is needed (mainly product development, and marketing-communications). Other than the pilgrimage, many other Church holidays should be advertised, which would increase the balanced popularity of the shrine itself.

\section{REFERENCES}

Bona, K., Seongseop, K., \& Brian, K. (2020). Religious tourism studies: evolution, progress, and future prospects. Tourism Recreation Research, 45(2), 185203. https://doi.org/10.1080/02508281.2019.1664084

Bond, N., Packer, J., \& Ballantyne, R. (2015). Exploring visitor experiences, activities and benefits at three religious tourism sites. International Journal of Tourism Research, 17(5), 471-481. https://doi.org/10.1002/jtr.2014

Butler, R.W. (2011). Tourism Area Life Cycle, Goodfellow Publishers Limited, Woodeaton, Oxford.

Fábián, A. (2010). Kultúralapú városfejlesztés, kreatív városok [Culture-based urban development, creative cities]. Közép-Európai Közlemények, 3(1), 90-99. (in Hungarian).

Harkányi, Sz.Zs., Horkay, N., \& Molnár, A. (2011). Esettanulmány - A Mária Út spirituális turista- és zarándokút létrehozása. In Puczkó L. \& Rátz T. (szerk.): Az attrakciótól az élményig. A látogatómenedzsment módszerei (pp. 75-89), [Case Study - Creating a Spiritual Tourist and Pilgrimage Route on Mary's Way. In Puczkó L. \& Rátz T. (ed.), From attraction to experience. Visitor management methods]. Akadémiai Kiadó, Budapest, Hungary.

Harangozó, I. (2003). Jézushágón. A csíksomlyói búcsújárásról és a kegyhely történetéről [About the pilgrimage in Csíksomlyó and the history of the shrine]. Kárpátia, 3/7, 39-44, (in Hungarian).

Irimiás, A., \& Michalkó, G. (2013). Religious tourism in Hungary - an integrative framework. Hungarian Geographical Bulletin, 62(2), 175-196.

Mester, T. (2006). Vallási turizmus [Religious tourism]. Turizmus Bulletin, 7(2), 16-18, (in Hungarian).

Mintel. (2012). Religious and Pilgrimage Tourism - International. Mintel International Group Ltd, London. http://reports.mintel.com/display/612230/

Mohay, T. (2006). Vonzáskör változásban: Búcsújárás Csíksomlyóra. In A Csíki Székely Múzeum Évkönyve [Area of attraction in change: Pilgrimage to Csíksomlyó. In Yearbook of the Csíki Székely Museum] (pp. 273-325), Csíkszereda, Romania.

Mohay, T. (2009). A csíksomlyói pünkösdi búcsújárás. Történet, eredet, hagyomány [The Pentecostal pilgrimage in Csíksomlyó. History, origin, tradition], L'Harmattan, Budapest, Hungary.

Nagy, B. (2013). A turisztikai helymarketing megalapozása Székelyföldön. Az imázs és márkahasználat tudományos megalapozása [Establishment of tourist place marketing in Szeklerland. Scientific substantiation of image and branding], Nemzeti Kisebbségkutató Intézet, Kolozsvár, Romania.

Palancsa, A. (2007). A turizmus társadalmi-kulturális hatásainak vizsgálata egy ökoturisztikai desztinációban. Turisztikai kutatás az Örségben [Investigation of the socio-cultural impacts of tourism in an ecotourism destination. Tourist research in Örség], Doctoral Dissertation, University of West Hungary Faculty of Economics Theory and Practice of Economic Processes Doctoral School, Sopron, Hungary.

Plog, S.C. (2001). Why destination areas rise and fall in popularity: an update of a Cornell Quarterly classic. The Cornell Hotel and Restaurant Administration Quarterly, 42(3), 13-24. https://doi.org/10.1016/S0010-8804(01)81020-X

Raffay, Á., Lőrincz, K., \& Clarke, A. (2014). Spirituális és üzleti értékek találkozása a vallási turizmusban [Meeting of spiritual and business values in religious tourism]. Turizmus Bulletin, 15(2), 34-42 (in Hungarian).

Santos, M. (2003). Religious Tourism: Contributions Towards a Clarification of Concepts. In Fernandes, C., McGettigan, F. \& Edwards, J. (Eds.): Religious Tourism and Pilgrimage. (pp. 27-41), ATLAS - Special Interest Group 1st Expert Meeting. Fatima, Tourism Board of Leiria. http://dx.doi.org/10.26449/sssj.1277.

Smith, V.L. (1992). Pilgrimage and Tourism: The Quest in Guest Annals of tourism research, Pergamon Press, Oxford.

Stausberg, M. (2011). Religion and Tourism. Crossroads, destinations and encounters, Routhledge. London - New York.

Suntikul, W., \& Dorji, U. (2016). Local Perspectives on the Impact of Tourism on Religious Festivals in Bhutan. Asia Pacific Journal of Tourism Research, 21(7), 741-762. https://doi.org/10.1080/10941665.2015.1069365

Tőzsér, A., \& Bánhidai, Cs. (2016). A csíksomlyói búcsú turisztikai vizsgálata 2016. Kutatási Jelentés. Kárpát-haza Program [Tourism study of the farewell in Csíksomlyó 2016. Research Report. Carpathian Home Program], Nemzetstratégiai Kutatóintézet, Budapest, Hungary.

Varga, J. (2011). A vallási turizmus jelenléte ma Magyarországon [The presence of religious tourism in Hungary today]. Keresztény Szó, 22(12), 16-21 (in Hungarian).

Vörös, G. (2005). A szakrális, a nemzeti közösség és az egzotikum élménye. A magyarországiak részvételének motivációiról a csíksomlyói pünkösdi [An experience of the sacred, the national community and the exotic. On the motivations of Hungarians to participate in the Pentecostal farewell in Csíksomlyó]. In Feischmidt M. (szerk.) Erdély- (de)konstrukciók. Tanulmányok. búcsúban (pp. 69-84), Néprajzi Múzeum-PTE Kommunikáció- és Médiatudományi Tanszék, Budapest - Pécs, Hungary.

Vukonic, B. (2002). Tourism and Religion. International Journal of Tourism Research, 4(4), 327-328. https://doi.org/10.1002/jtr.309

*** Interview with Erik Urbán, the provincial leader of the Transylvanian Franciscans and the church director of the Franciscan monastery of Csíksomlyó.

*** UNWTO (2011). Religious Tourism in Asia and the Pacific, World Tourism Organization, Madrid.
Article history:
Received: 21.07 .2020
Revised: 29.08.2020
Accepted: 12.10.2020
Available online: 27.10 .2020 